\title{
In Vitro Translocation Experiments with RxLR-Reporter Fusion Proteins of Avr1b from Phytophthora sojae and AVR3a from Phytophthora infestans Fail to Demonstrate Specific Autonomous Uptake in Plant and Animal Cells
}

\author{
Stephan Wawra, ${ }^{1}$ Armin Djamei, ${ }^{2}$ Isabell Albert, ${ }^{3}$ Thorsten Nürnberger, ${ }^{3}$ Regine Kahmann, ${ }^{2}$ and \\ Pieter van West ${ }^{1}$ \\ ${ }^{1}$ Aberdeen Oomycete Laboratory, University of Aberdeen, Institute of Medical Sciences, Foresterhill, Aberdeen, AB25 2ZD, \\ U.K.; ' ${ }^{2}$ Department of Organismic Interactions, Max Planck Institute for Terrestrial Microbiology, Karl-von-Frisch-Straße 10, \\ Marburg, 35043, Germany; ${ }^{3}$ Department of Plant Biochemistry, Center for Plant Molecular Biology, Eberhard Karls \\ University, Auf der Morgenstelle 5, Tübingen, 72076, Germany
}

Submitted 11 August 2012. Accepted 23 January 2013.

\begin{abstract}
Plant-pathogenic oomycetes have a large set of secreted effectors that can be translocated into their host cells during infection. One group of these effectors are the RxLR effectors for which it has been shown, in a few cases, that the RxLR motif is important for their translocation. It has been suggested that the RxLR-leader sequences alone are enough to translocate the respective effectors into eukaryotic cells through binding to surface-exposed phosphoinositol-3-phosphate. These conclusions were primary based on translocation experiments conducted with recombinant fusion proteins whereby the RxLR leader of RxLR effectors (i.e., Avr1b from Phytophthora sojae) were fused to the green fluorescent protein reporter-protein. However, we failed to observe specific cellular uptake for a comparable fusion protein where the RxLR leader of the $P$. infestans AVR3a was fused to monomeric red fluorescent protein. Therefore, we reexamined the ability of the reported $P$. sojae AVR1b RxLR leader to enter eukaryotic cells. Different relevant experiments were performed in three independent laboratories, using fluorescent reporter fusion constructs of AVR3a and Avr1b proteins in a side-by-side comparative study on plant tissue and human and animal cells. We report that we were unable to obtain conclusive evidence for specific RxLR-mediated translocation.
\end{abstract}

Most plant-pathogenic oomycetes have a large number of putative effector proteins that are thought to be able to translocate into host cells during infection (Bernoux et al. 2011; Birch et al. 2009; He et al. 2004; Mattoo et al. 2007; Rehmany et al. 2005; Stergiopoulos and de Wit, 2009). One group of such effectors are the so-called RxLR effectors, which have a

All of the authors contributed equally to this work.

Corresponding author: P. van West; E-mail: p.vanwest@ abdn.ac.uk

* The $\boldsymbol{e}$-Xtra logo stands for "electronic extra" and indicates that seven supplementary figures, two supplementary tables, and a supplementary appendix are published online.

(C) 2013 The American Phytopathological Society signal peptide for secretion and an arginine-any amino acidleucine-arginine sequence within the first 40 amino acids after the signal peptide cleavage site (Birch et al. 2009; Rehmany et al. 2005; Whisson et al. 2007). In recent years, it has become clear that these RxLR effectors are important for infection because they interfere with the host defense system (Bozkurt et al. 2012; Ravensdale et al. 2011).

At present, it is not really clear what constitutes a "true or real" RxLR effector and how to distinguish these from proteins that possess an RxLR motif only by chance. For example, it is unclear whether SpHtp1, a putative effector from the fish-pathogenic oomycete Saprolegnia parasitica, is an RxLR effector. The protein contains the signature amino acids (RxLR) at the right position in the primary sequence and is delivered by the pathogen inside cells under attack (van West et al. 2010) but this protein lacks the W-Y motif commonly found in plantpathogenic oomycete RxLR effectors (Boutemy et al. 2011; Dou et al. 2008a; Yaeno et al. 2011). Furthermore, the RxLR proteins seems to be under positive selection in plant-pathogenic oomycetes such as Phytophthora spp. and downy mildews species (Baxter et al. 2010; Haas et al. 2009), whereas this does not seem to be the case in Saprolegnia spp. Therefore, this protein is currently classified as RxLR-like.

Some recent studies have suggested that the host cell translocation properties of RxLR effectors reside in the RxLRleader sequence (Dou et al. 2008b; Kale et al. 2010; Whisson et al. 2007). Therefore, it is generally assumed that, in these proteins, the RxLR leader is responsible for host cell translocation and is followed by an effector domain located at the Cterminus. Furthermore, there is some evidence which suggests that RxLR effectors are able to "self-translocate" without the presence of the pathogen, suggesting that the translocation machinery is present in the host itself (Dou et al. 2008b; Kale et al. 2010; Wawra et al. 2012).

Most studies examining the delivery of RxLR effectors from oomycete pathogens into host cells are based on indirect evidence. For example, genetic transformations of the oomycete pathogen Phytophthora infestans with an RxLR effector (AVR3a) and truncation and mutation reporter constructs thereof have demonstrated that the reporters are translocated into host cells (Whisson et al. 2007). Furthermore, race-specific 
host resistance has been used to demonstrate a hypersensitive response after (agro)-infiltration with several RxLR effectors (Bos et al. 2006, 2010; Grouffaud et al. 2008; Whisson et al. 2007; Yaeno et al. 2011). At present, there is only one study, which is based on SpHtp1 from the fish pathogen S. parasitica, that could show the translocation of an endogenous RxLR-like protein directly during infection, by employing immunolocalization techniques (van West et al. 2010).

Several studies report that translocation of RxLR(-like) proteins, or derivatives thereof, into host cells and nonhost cells is taking place and that these proteins do not require any pathogen-encoded machinery for this process. These studies are based on generation and purification of recombinant RxLR proteins that are subsequently used in infiltration or bathing experiments (Dou et al. 2008b; Kale et al. 2010; Plett et al. 2011; Wawra et al. 2012). In particular, a fusion protein in which the RxLR leader of $P$. sojae Avr1b is fused to green fluorescent protein (GFP) was reported to translocate in the absence of the pathogen into onion, soybean, and human A549 cells (Dou et al. 2008b; Kale et al. 2010). Because we failed to see uptake of a similar fusion protein into plant cells, we decided to investigate this further by verifying experiments performed by Dou and associates (2008b) and Kale and associates (2010) in three independent laboratories, which are located in Aberdeen, United Kingdom, and Marburg and Tübingen, Germany. These laboratories conducted different sets of experiments, all relevant to the independent host cell entry results described by Dou and associates (2008b) and Kale and associates (2010). Our findings are in contrast with the observations previously made and provide no evidence that the RxLR leaders of Avr1b and AVR3a are able to self-translocate.

\section{RESULTS}

In order to study the translocation behavior of the AVR3a RxLR leader, the N-terminal amino acids 22 to 59 (lacking the predicted signal peptide) were fused to monomeric red fluorescent protein (mRFP). The corresponding recombinant protein, AVR $3 \mathrm{a}^{22-59} \mathrm{mRFP}(\mathrm{His})_{6}$, was purified and characterized (Supplementary Fig. S1A). Additionally, the ability of AVR3a ${ }^{22-59}$ mRFP(His $)_{6}$ to enter cells of different eukaryotic species was evaluated by bathing onion epidermis, RTG-2 (a trout gonad cell line), and HEK293 (a human embryonic kidney cell line) cells and A549 (a human lung carcinoma cell line) for $2 \mathrm{~h}$ in a $15-\mu \mathrm{M}$ protein solution. No specific uptake of AVR $3 \mathrm{a}^{22-59}$ mRFP(His $)_{6}$ could be detected in any of the used cell types whereas the previously reported fish-cell-specific translocating protein SpHtp1 ${ }^{24-68} \mathrm{mRFP}(\mathrm{His})_{6}$ and the fluorescein isothiocyanate (FITC) 488-labeled lectin wheat germ agglutinin (WGA) showed (at five times lower concentrations) an efficient uptake already after $1 \mathrm{~h}$ (Wawra et al. 2012) (Fig. 1). Dou and associates (2008b) and Kale and associates (2010) reported that, in similar experiments with Avr1b, which is an AVR3a homologue from $P$. sojae, a recombinant RxLR-leader-GFP-fusion reporter protein was able to enter eukaryotic cells of different origins. However, the translocation experiments that were described before by Kale and associates (2010) differed from the experiments we performed here with AVR $3 \mathrm{a}^{22-59} \mathrm{mRFP}(\mathrm{His})_{6}$ by the following parameters: i) five times longer incubation periods were utilized by Kale and associates (2008) with ii) higher protein concentration and iii) in the case of soybean root cell uptake assays, a pH 5.8 buffered solution was used. Therefore, we first repeated the uptake experiments with protein solutions adjusted to $\mathrm{pH}$ 5.8. Again, we compared the uptake of AVR3 $\mathrm{a}^{22-59} \mathrm{mRFP}(\mathrm{His})_{6}$ with mRFP(His) ${ }_{6}$ on RTG-2, HEK293, and soybean root cells but found no fluorescent sig- nals inside the utilized cells after $2 \mathrm{~h}$ of incubation (Supplementary Fig. S2A, B, and D).

In similar assays that have been described in the literature using proteins that are able to enter cells, the proteins are usually detected inside the respective cell types after short incubation times (Figs. 1E to G and 2) (Liu et al. 2011; Plett et al. 2011; Sharon 1984; Wawra et al. 2012).

Therefore, we decided to compare our results obtained with AVR $3 a^{22-59}$ mRFP(His) ${ }_{6}$ with that of the published Avr1b GFPreporter construct to determine whether the AVR3a-reporter construct was, indeed, unable to translocate. Thus, the DNA sequence of Avr1b RxLR-GFP construct from $P$. sojae (Dou et al. 2008b; Kale et al. 2010) was synthesized (GenScript), cloned into pET21b, overexpressed, and purified. This construct contains the RxLR-region of Avr1b fused to the green fluorescent reporter gene exactly as it was described by Dou and associates (2008b) and Kale and associates (2010). According to the protein sequence for (His) ${ }_{6} \mathrm{Avr} 1 \mathrm{~b}^{33-71} \mathrm{GFP}$, the expected molecular mass for this protein is $38,977 \mathrm{Da}$. The matrix-assisted laser desorption ionization time-of-flight mass spectrometric analysis of the purified protein showed a mass of $38 \mathrm{~m} 943.1$ $\mathrm{Da}$. The mass difference between the theoretical expected and the measured mass resulted from the loss of two water molecules during the formation of the green fluorescent chromophore (Heim et al. 1994; Reid and Flynn 1997). Side-by-side comparison of the mRFP and GFP fluorescence should be valid because both differ only slightly in their relative brightness, with GFP being the more potent fluorophore (Supplementary Table S1).

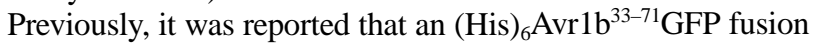
protein is able to enter onion skin epidermal, soybean root, and human A549 cells (Dou et al. 2008b; Kale et al. 2010). When we used this fusion protein in our experimental setup, we were not able to detect any translocation with $15 \mu \mathrm{M}$ protein after 1 to $2 \mathrm{~h}$ of incubation on soybean root, RTG-2 (fish), and HEK293 cells. To verify our results further, we also performed similar uptake experiments utilizing A549 cells (as were used by Kale and associates [2010]) and tested for protein uptake of

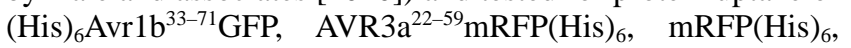
and FITC-labeled WGA after $2.5 \mathrm{~min}, 10 \mathrm{~min}, 1 \mathrm{~h}$, and $9 \mathrm{~h}$ (Fig. 2). The positive control protein WGA showed translocation into A549 cells with signal intensities increasing over time, whereas the other tested fusion proteins did not appear inside the cells. For further evaluation, we tested a variety of different combinations of incubation times, cell types, and $\mathrm{pH}$ values and compared the fluorescent signals obtained with mRFP(His) $)_{6}$ with AVR3 $\mathrm{a}^{22-59} \mathrm{mRFP}(\mathrm{His})_{6}$ and (His) ${ }_{6} \mathrm{Avr} \mathrm{b}^{33-71}$ GFP (Figs. 2 to 4; Supplementary Figs. S3 to S6). A summary of all incubation conditions that were evaluated can be found in Supplementary Table S2. In none of the performed experiments could we detect a significant difference between the three fluorescent proteins, nor could we detect any convincing evidence for an RxLR-dependent uptake into any of the used cell types. In the case of the soybean root uptake experiment, the positive uptake shown for any tested protein, including the negative control, under the given conditions indicated that the test system is not suitable to investigate any potential specific uptake. We noted that incubations under acidic conditions ( $\mathrm{pH}$ 5.8) generally gave stronger fluorescent signals on all cell types with all fusion proteins, including $\mathrm{mRFP}(\mathrm{His})_{6}$ (Fig. 4). This $\mathrm{pH}$ is very close to the theoretical isoelectric point $(\mathrm{pI})$ of the used proteins $\left(\mathrm{AVR} 3 \mathrm{a}^{22-59} \mathrm{mRFP}(\mathrm{His})_{6}, \mathrm{pI}=\right.$ 5.97; (His) ${ }_{6}$ Avr $1 b^{33-71} \mathrm{GFP}, \mathrm{pI}=5.69$; and $\mathrm{mRFP}(\mathrm{His})_{6}, \mathrm{pI}=$ $6.01)$ and, therefore, will induce protein aggregation. In particular, (His) ${ }_{6}$ Avr $1 b^{33-71}$ GFP showed a tendency toward aggregation at pH 5.8 (Supplementary Fig. S7), and longer incubations at this $\mathrm{pH}$ on cells led to significant numbers of green fluores- 
AVR3a RxLR-leader mRFP fusion

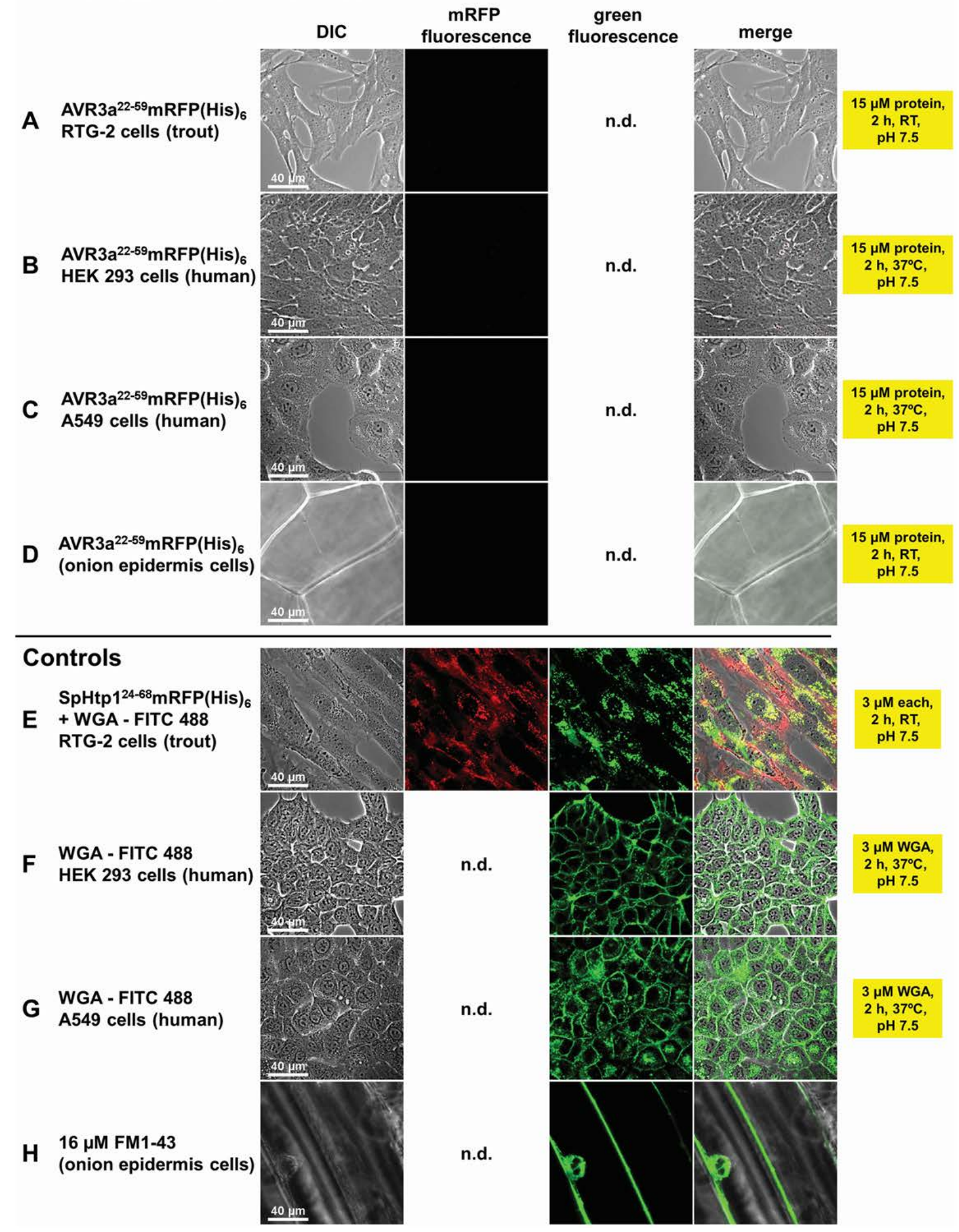

Fig. 1. N-terminal RxLR-leader peptide of AVR3a (amino acids 22 to 59) is not a self-translocating polypeptide. A to D The RxLR-leader monomeric red fluorescent protein (mRFP) fusion protein, AVR3 $\mathrm{a}^{22-59} \mathrm{mRFP}(\mathrm{His})_{6}$, is not able to enter A, rainbow trout gonad cells (RTG-2 cell line); B, human-derived HEK293 cells; C, human A549 cells (lung carcinoma); or D, onion epidermis cells. E, In contrast, RTG-2 cells that were incubated for $1 \mathrm{~h}$ with $3 \mu \mathrm{M}$ $\mathrm{SpHtp1}^{24-68} \mathrm{mRFP}(\mathrm{His})_{6}$ and fluorescein isothiocyanate (FITC) 488-labeled wheat germ agglutinin (WGA) at $10 \mu \mathrm{g} / \mathrm{ml}$ showed a strong fluorescent uptake. WGA is also efficiently taken up in F, HEK293 and G, A549 cells. H, Membrane dye FM1-43 was used as a viability control on onion epidermis cells. Incubation of RTG-2 cells was carried out with $15 \mu \mathrm{M}$ AVR3 $\mathrm{a}^{22-59} \mathrm{mRFP}(\mathrm{His})_{6}\left(3 \mu \mathrm{M} \mathrm{SpHtp} 1^{24-68} \mathrm{mRFP}(\mathrm{His})_{6}\right)$ in L15 medium containing $10 \%$ fetal calf serum (FCS) for the RTG-2 cells and in Dulbecco's modified eagle medium (+10\% FCS) for the HEK293 and A549 cells. Incubation of onion epidermis cells was carried out in phosphate-buffered saline (PBS) containing 10\% bovine serum albumin (BSA). Incubation temperatures are indicated. Red channel: mRFP fluorescence; white channel: DIC; green channel: FITC fluorescence; n.d. = not determined. 
cent particles (easily seen in "cell-free" areas in Figure 4G) that could not be entirely washed away.

\section{DISCUSSION}

The question of how RxLR effectors from plant-pathogenic oomycetes enter plant cells is an important one, and conflicting results have been reported previously on the subject (Bozkurt et al. 2012; Ellis and Dodds 2011; Kale and Tyler 2011). Here, we reinvestigated whether RxLR leaders of oomycete RxLR effectors possess a self-translocation activity that can direct these proteins into eukaryotic cells of different origin. We studied the translocation behavior of two RxLRleader reporter fusions originating from the RxLR effectors AVR3a from $P$. infestans and Avr1b from $P$. sojae. Translocation experiments utilizing a recombinant RxLR-mRFP fusion protein based on AVR3a showed that this protein was unable to specifically enter animal or plant cells (Figs. 1 to 4). However, similar experiments published earlier utilizing GFP as a reporter fused $\mathrm{N}$-terminally with RxLR leaders of different oomycete (and fungal) effectors reported successful translocation of these into several eukaryotic cell types (Dou et al. 2008b; Kale and Tyler 2011; Kale et al. 2010). Such fusion proteins were reported to enter onion, soybean root, and human A549 cells after an overnight incubation (Dou et al. 2008b; Kale et al. 2010). Because AVR3a and Avr1b are closely related proteins from two different Phytophthora spp. but share high sequence homology in the RxLR leader and the C-terminal effector domains (sequence alignment), we decided to verify some of the experiments described by Dou and associates (2008b) and Kale and associates (2010) using exactly the same Avr1b-GFP fusion protein. Three independent laboratories were involved in different experiments comparing, side by side, the cellular uptake of the two reporter fusions AVR $3 \mathrm{a}^{22-59} \mathrm{mRFP}(\mathrm{His})_{6}$ and (His) ${ }_{6} \mathrm{Avr}^{2} \mathrm{~b}^{33-71} \mathrm{GFP}$ alongside control fluorescent proteins.

We found that the (His) ${ }_{6}$ Avr $1 b^{33-71}$ GFP fusion protein behaved very similarly to the AVR $3 \mathrm{a}^{22-59} \mathrm{mRFP}(\mathrm{His})_{6}$ fusion protein, which meant that protein uptake into animal cells after an overnight incubation was absent. In plant cells, uptake was observed in some parts of the root, but in such areas, the negative control protein (mRFP(His) $)_{6}$ ) also was taken up (Figs. 2 to 4 ). Short time incubations (approximately 1 to 2 h) failed to show any protein uptake in any of the tested cell types at all (Fig. 2). The experiments shown here differ in one aspect from the original published work. The experiments described by Dou and associates (2008b) utilized an (His) ${ }_{6}$ Avr $1 b^{33-71}$ GFP concentration of $8 \mathrm{mg} / \mathrm{ml}$ which corresponds to a molar protein concentration of $205 \mu \mathrm{M}$. Kale and associates (2010), reported uptake also when using $1 \mathrm{mg} / \mathrm{ml}$ $(=25 \mu \mathrm{M})$. In general, approximately $20 \%$ of the mass of an average eukaryotic cell is made up of proteins, which results in a value of approximately $250 \mathrm{mg} / \mathrm{ml}$. Some highly abundant proteins can accumulate up to $1 \%$ of the total protein

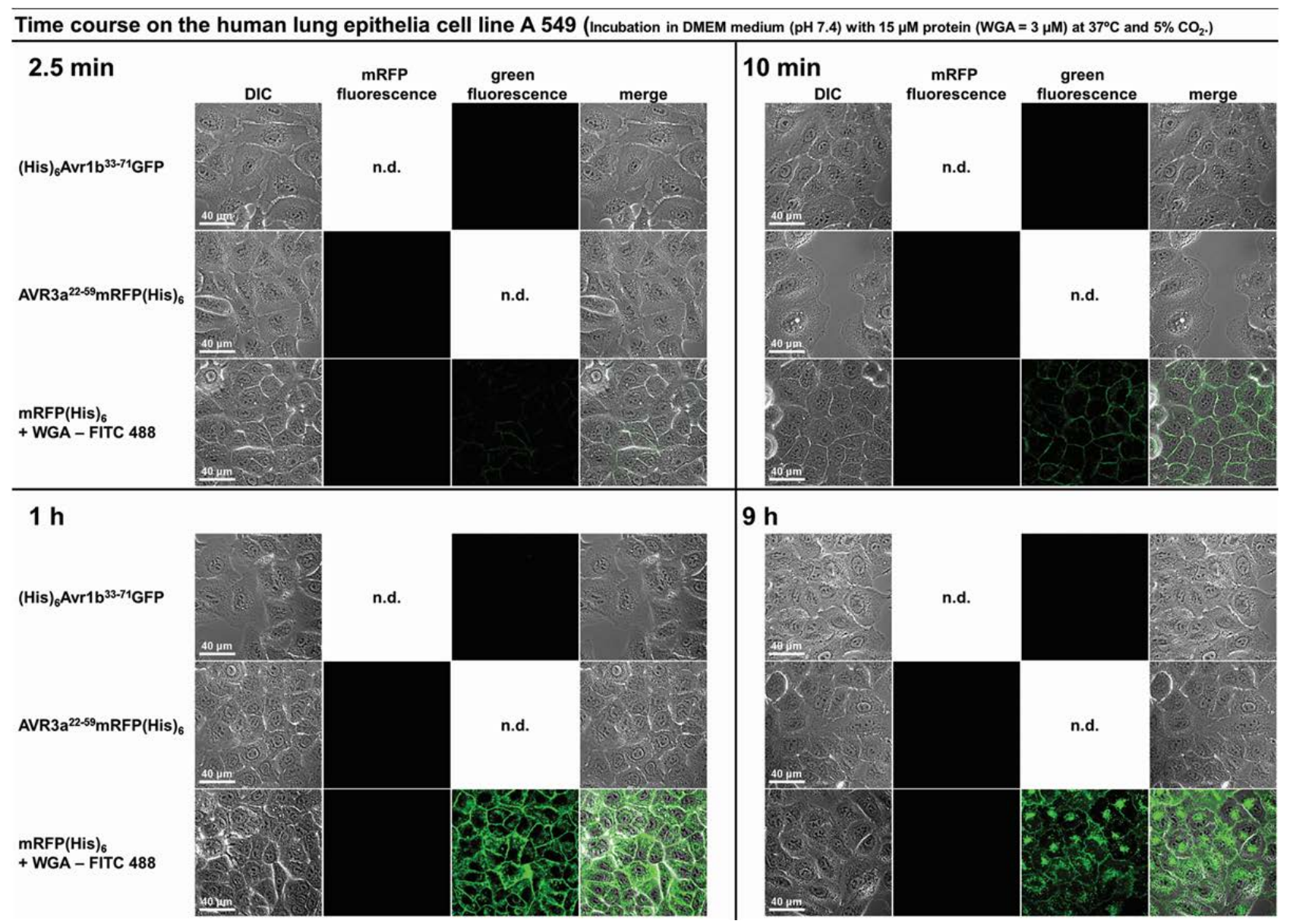

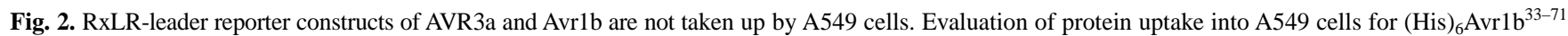
green fluorescent protein (GFP), AVR3 $\mathrm{a}^{22-59}$ monomeric red fluorescent protein (mRFP)(His) 6 , mRFP(His) 6 , and fluorescein isothiocyanate (FITC)-labeled wheat germ agglutinin (WGA) was determined at the indicated time points. Incubation was carried out with $15 \mu \mathrm{M}$ mRFP(His) ${ }_{6}$ co-incubated with WGA at $10 \mu \mathrm{g} / \mathrm{ml}$ in Dulbecco's modified eagle medium containing $10 \%$ fetal calf serum (FCS) at $37^{\circ} \mathrm{C}$ in an atmosphere of $5 \% \mathrm{CO}_{2}$. Red channel: $\mathrm{mRFP}$ fluorescence; white channel: DIC; green channel: FITC fluorescence; n.d. = not determined. 
mass (Malmstrom et al. 2009). For example, $\beta$-tubulin has been reported to be present in a concentration of approximately $40 \mu \mathrm{M}$ (Hiller and Weber 1978). For most proteins, the physiological concentration in the cell is in the nano- to picomolar range (Malmstrom et al. 2009) and, in some cases, might locally achieve low micromolar concentrations. Thus, observations resulting from cells exposed to high protein concentrations (e.g., 205 or even $25 \mu \mathrm{M}$ ) have to be treated with care. Certainly, the total protein amount presented to a cell in such an in vitro bathing experiment will largely exceed the available amount during an infection. Therefore, the reaction kinetics are important and need to be considered carefully. The reports describing the translocation of (His) 6 Avr1b ${ }^{33-71}$ GFP state that 8 - to 12 -h incubation times were required in order to properly image protein uptake. When we exposed soybean roots, RTG-2, HEK293, or A549 cells for more than $9 \mathrm{~h}$ to (His) ${ }_{6}$ Avr1b $\mathrm{b}^{33-71} \mathrm{GFP}$ (up to $15 \mu \mathrm{M}$ ) under neutral $\mathrm{pH}$ conditions, we did not observe any significant difference in the obtained fluorescence of the latter compared with the negative control protein mRFP(His) 6 (Figs. 2 to 4). Proteins that are well known to be able to enter the respective cells-for example, the C-type lectin WGA (Kerrigan and Brown 2009) or SpHtp1 (Wawra et al. 2012) — can normally be visualized intracellularly within minutes (exemplarily shown in Figure 2).
A fact that could contribute to the reported observations by Dou and associates (2008b) and Kale and associates (2010) might be found in the buffer conditions. There, the buffer reported for protein storage and the soybean root assays was adjusted to pH 5.8 (Dou et al. 2008b; Kale et al. 2010). This $\mathrm{pH}$, very close to the theoretical $\mathrm{pI}$ of GFP $(\mathrm{pI}=5.67)$ and (His) ${ }_{6}$ Avr $1 b^{33-71} \mathrm{GFP}(\mathrm{pI}=5.69)$, clearly induced protein precipitation in vitro and after long incubations on cells at this $\mathrm{pH}$ (Fig. 4G). However, this cannot explain the observed differences in uptake in one case and failure in the experiments presented here.

Furthermore, roots of several plants have been found to endocytose unspecific proteins such as bovine serum albumin (BSA) or GFP as nitrogen sources already after $1.5 \mathrm{~h}$, when nitrogen sources become limiting (Paungfoo-Lonhienne et al. 2008). These reported observations appear to be very similar to what we found after incubating $\operatorname{mRFP}(\mathrm{His})_{6}$, ( $\left.\mathrm{His}\right)_{6} \mathrm{Avr} \mathrm{b}^{33-71}$ GFP, and AVR $3 \mathrm{a}^{22-59} \mathrm{mRFP}(\mathrm{His})_{6}$ on soybean and Arabidopsis roots (Figs. 3 and 4). Consequently, we feel that results obtained after long incubations have to be treated with care because results might be caused by a lack of nitrogen in the solution. In addition, we were unable to detect a specific nuclear localization of (His) ${ }_{6}$ Avr1b ${ }^{33-71}$ GFP as was described by Dou and associates (2008b) and Kale and associates (2010). However, occasionally, the control protein $\operatorname{mRFP}(\mathrm{His})_{6}$ was observed in

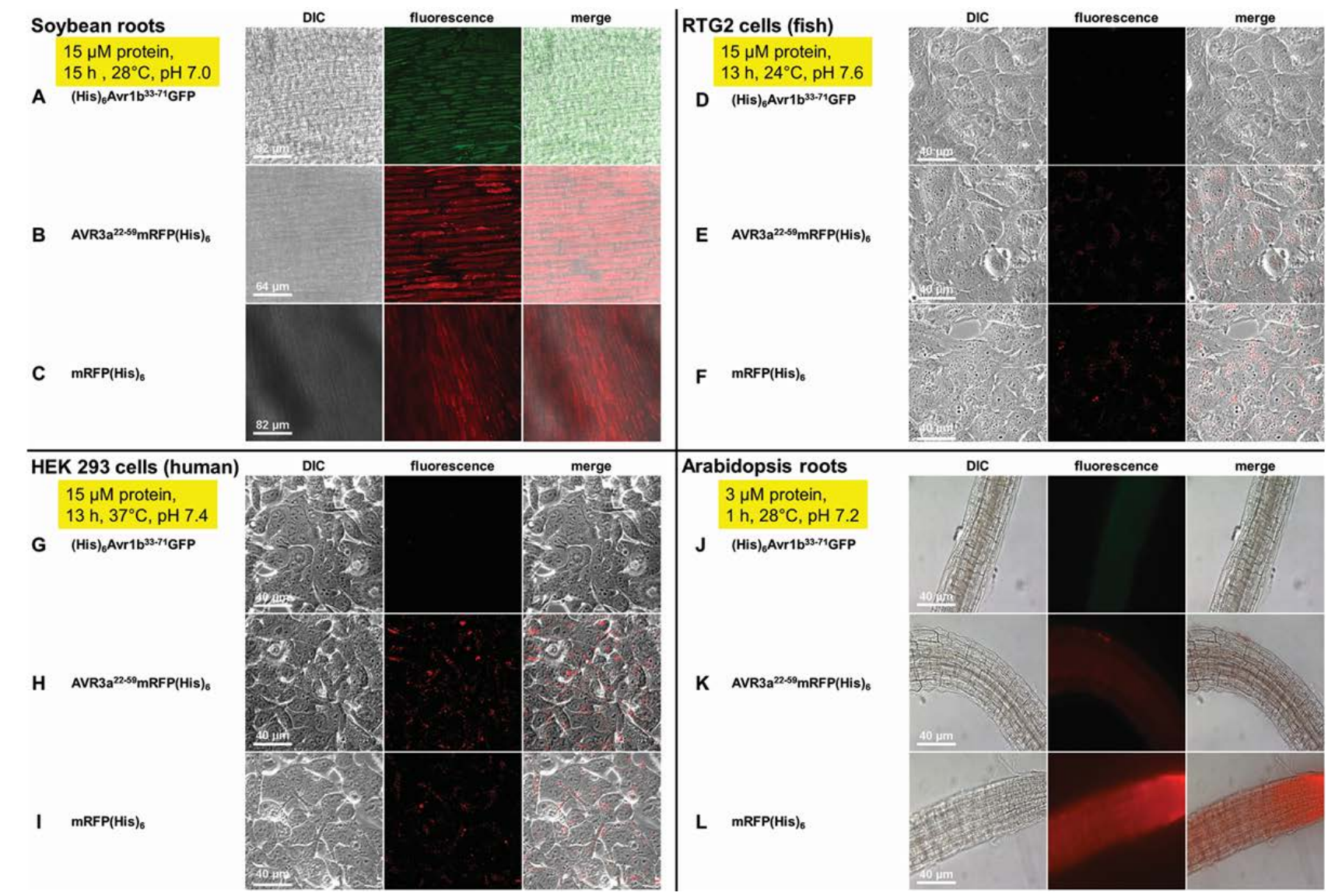

Fig. 3. Comparison of the fluorescence uptake into different cell types of (His) ${ }_{6}$ Avr $1 b^{33-71}$ green fluorescent protein (GFP), AVR3a ${ }^{22-59}$ monomeric red fluorescent protein $(\mathrm{mRFP})(\mathrm{His})_{6}$, and $\mathrm{mRFP}(\mathrm{His})_{6}$ after overnight incubations at neutral $\mathrm{pH}$. A to $\mathbf{C}$, Uptake assay with soybean roots utilizing the respective proteins at $15 \mu \mathrm{M}$ in $50 \mathrm{mM}$ sodium phosphate buffer, $\mathrm{pH}$ 7.0. No difference in the fluorescence uptake could be observed for all three recombinant proteins. $\mathbf{D}$ to $\mathbf{F}$ and $\mathbf{G}$ to $\mathbf{I}$, Images obtained after $13 \mathrm{~h}$ of incubation with the respective protein constructs at $15 \mu \mathrm{M}$ on the rainbow trout gonad cell line RTG- 2 and the human HEK293 cell line in the respective cell culture medium containing $10 \%$ fetal calf serum (FCS). For AVR3a ${ }^{22-59}{ }_{\text {mRFP(His) }}$ and mRFP(His) 6 equally, weak fluorescence signals were detected on both cell lines, probably caused by an unspecific uptake (e.g., pinocytosis). In contrast, after incubation with (His) ${ }_{6}$ Avr $1 b^{33-71}$ green fluorescent protein (GFP), no GFP fluorescence was detected even when the incubation solution was still green fluorescent. $\mathbf{J}$ to $\mathbf{L}$, After incubation of Arabidopsis roots with $3 \mu \mathrm{M}$ each protein construct for $1 \mathrm{~h}$ in $50 \mathrm{mM}$ sodium phosphate buffer, pH 7.2 , followed by $3 \times 15 \mathrm{~min}$ of washing in buffer, comparable fluorescence signals were detected for AVR $3 \mathrm{a}^{22-59} \mathrm{mRFP}(\mathrm{His})_{6}$ and (His) ${ }_{6}$ Avr1 $\mathrm{b}^{33-71} \mathrm{GFP}$. With mRFP(His) ${ }_{6}$, an even stronger fluorescence signal could be observed. DIC: differential phase contrast; green channel: GFP fluorescence; red channel: mRFP fluorescence. 
the nucleus of some soybean root cells after long incubation at $\mathrm{pH}$ 5.8, showing that unspecific nuclear uptake is possible.

In summary, we were unable to independently verify a key observation made by Dou and associates (2008b) and Kale and associates (2010), which implied that the RxLR leader of Avr1b fused to GFP is able to self-translocate in host and nonhost cells. Only after prolonged incubation times were the RxLR-leader reporter constructs of AVR3a and Avr1b found inside the tested cell types; however, so was the negative control protein. In contrast, the fluorescent reporter proteins that were used as positive controls showed fast translocation kinetics at lower protein concentrations. Consequently, these data do not support the model that RxLR leaders of RxLR effectors are self-translocating polypeptides. Further refinement of experiments, better biochemical characterization of (recombinant) proteins, more careful interpretation of obtained data, and more rigid controls are required in future research to elucidate the RxLR-mediated translocation system of oomycete pathogens.

\section{MATERIALS AND METHODS}

Chemicals.

Buffers were purchased from AppliChem (Darmstadt, Germany) and Merck (Darmstadt, Germany). All other chemicals were purchased from Sigma (Munich) and were of the highest purity available.

\section{Polymerase chain reaction, primer, cloning, and protein expression conditions.}

Polymerase chain reaction (PCR) reactions were performed using the following primer combinations: FW, 5'-CTCCGTCG ACATGGCCTCCTCCGAGGA-3' and RW, 5'-CACTCCACC GGCGCCAAAGCGGCCGCACT-3' (for vector pET21b, cloning sites Sal1/Not 1 , construct mRFP; FW, 5' GCATCATATGA TCGACCAAACCAAGGTCCTG $3^{\prime}$ and RW, 5'-CTAGGAAT TCGGTCGCTCCTCAGACGTTTC- $3^{\prime}$ for vector pET21b, cloning sites $N D E 1 / E c o R 1$, construct AVR3a ${ }^{22-59}$ ), with KODHot start DNA polymerase (Novagen; lot number M00057770). The PCR products were blunt end cloned into pETblue-2 or pUC19, digested using the NdeI and EcoRI restriction sites embedded in the primers, and subcloned in precut pET $21 \mathrm{~b}$. The resulting fragments were in frame with the (His) ${ }_{6}$ tag encoded by pET21b. mRFP was cloned into pET21b using the SalI/NotI cleavage sites. These are located $3^{\prime}$ from the NdeI and EcoRI and in frame with the (His) ${ }_{6}$ tag of the vector. The DNA template for the (His) ${ }_{6}$ Avr $1 b^{33-71}$ GFP was purchased from Genscript, Piscataway, NJ, U.S.A..

The sequenced constructs in pET21b were transformed in Escherichia coli Rosetta gami B (DE3, pLys; Novagen, Madi-

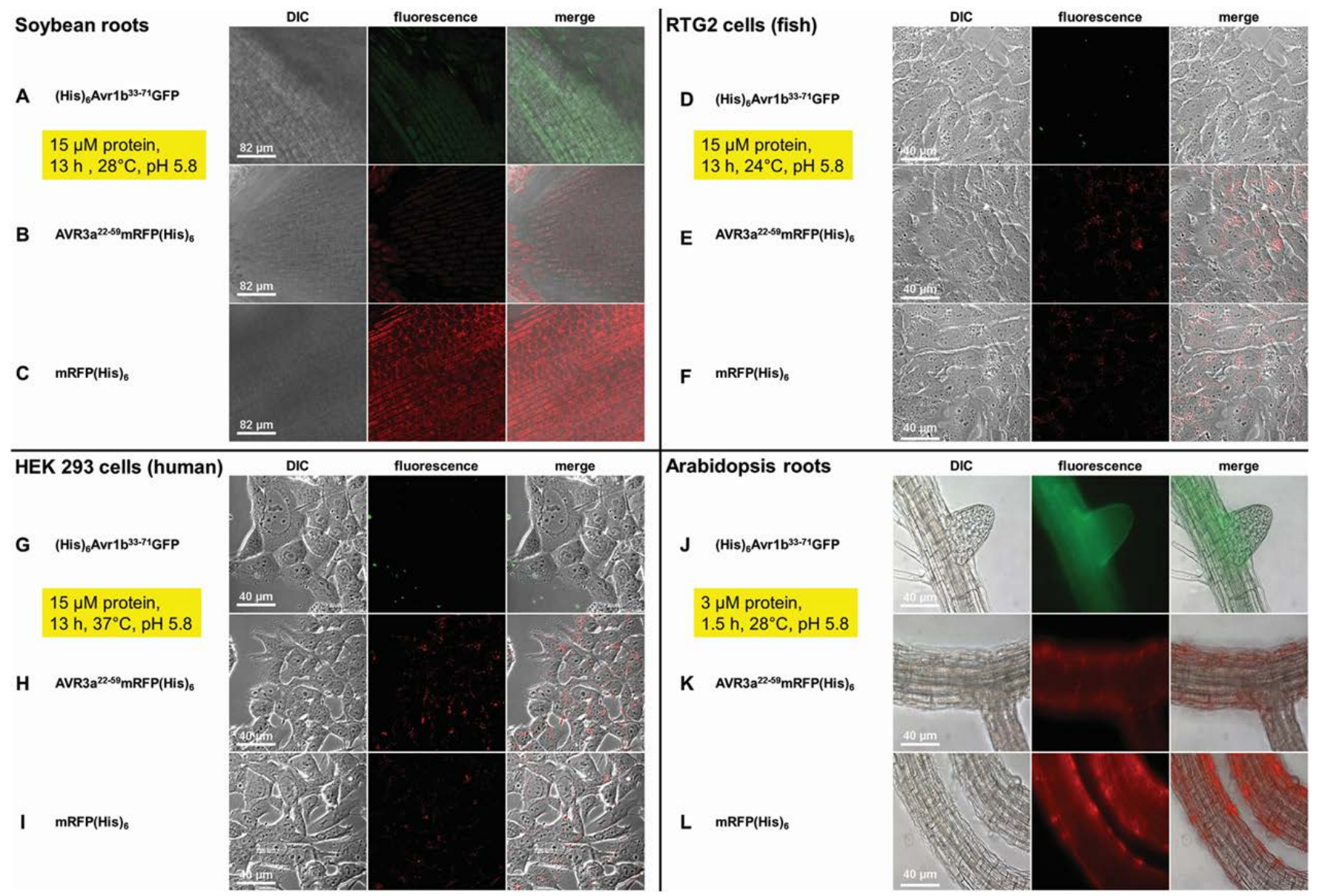

Fig. 4. Comparison of fluorescence uptake into A to $\mathbf{C}$, soybean roots, D to F, RTG2 cells, G to I, HEK 293 cells, or J to L, Arabidopsis roots of (His) ${ }_{6}$ Avr $1 b^{33-71}$ green fluorescent protein (GFP), AVR3 $\mathrm{a}^{22-59}$ monomeric red fluorescent protein (mRFP)(His) 6 , and mRFP(His) $)_{6}$ under acidic conditions (pH 5.8). $\mathbf{D}$ to $\mathbf{L}$, Although the detected fluorescence appeared to be slightly stronger after incubation at $\mathrm{pH} 5.8$ compared with the images obtained for experiments carried out at neutral $\mathrm{pH}$, no significant differences between the three protein constructs could be observed. However, we noted the presence of large numbers of protein aggregates for (His) $)_{6}$ Avr $1 \mathrm{~b}^{33-71} \mathrm{GFP}$ and AVR $3 \mathrm{a}^{22-59} \mathrm{mRFP}(\mathrm{His})_{6}$ after the incubation. $\mathbf{J}$ to $\mathbf{L}$, After incubation of Arabidopsis roots

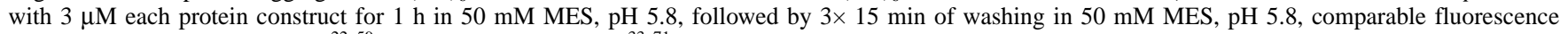
signals were detected for AVR3 $\mathrm{a}^{22-59} \mathrm{mRFP}(\mathrm{His})_{6}$, (His) ${ }_{6} \mathrm{Avr} 1 \mathrm{~b}^{33-71} \mathrm{GFP}$, and mRFP(His) $)_{6}$. DIC: differential phase contrast; green channel: GFP fluorescence; red channel: mRFP fluorescence. 
son, WI, U.S.A.) cells and overexpressed under the control of the T7 promoter. For protein expression, cells where grown in Luria-Bertani media to an optical density at $600 \mathrm{~nm}$ (for (His) ${ }_{6}$ Avr1b $^{33-71}$ GFP, $0.1 \%$ glucose was added) between 0.6 and 0.8 and induced with $1 \mathrm{mM}$ isopropyl-thio-galactopyranoside for $6 \mathrm{~h}$ at $37^{\circ} \mathrm{C}$. The cells were resuspended in $40 \mathrm{ml}$ of $50 \mathrm{mM}$ sodium phosphate $\mathrm{pH} 7.5$ and incubated for $20 \mathrm{~min}$ with $250 \mathrm{U}$ of Benzonase (Sigma), two tablets of protease inhibitor (number 11873580001 ; Roche, Branchburg, NJ, U.S.A.), and $0.1 \mathrm{~g}$ of lysozyme (number 62971; Fluka, Milwaukee, WI, U.S.A.). After the incubation, the solution was French pressed and diluted 1:5 in the respective buffer, and the soluble fraction was separated from the nonsoluble by centrifugation at $50,000 \times g$ for $1 \mathrm{~h}$.

\section{Column specifications.}

Specifications were as follows: NTA column, $15 \mathrm{ml}$ of NTA agarose (number 60-0441; Invitrogen, Carlsbad, CA, U.S.A.), column dimensions of $1 \mathrm{~cm}$ diameter, $20 \mathrm{~cm}$ height; $\mathrm{SO}_{3}{ }^{-}$ column: $40 \mathrm{ml}$ of Fractogel-EMD- $\mathrm{SO}_{3}^{-}$(M) (number 1.16882.0100; Merck), column dimensions of $2 \mathrm{~cm}$ diameter, $20 \mathrm{~cm}$ height; and QAE column, $35 \mathrm{ml}$ of QAE-sephadex A25 (number 17-0190-01; GE Healthcare, Piscataway, NJ, U.S.A.), column dimensions of $2 \mathrm{~cm}$ diameter, $20 \mathrm{~cm}$ height.

\section{Purification of $\mathrm{mRFP}(\mathrm{His})_{6}$.}

The French press supernatant was adjusted to $\mathrm{pH} 7.5$ and passed onto the $\mathrm{SO}_{3}{ }^{-}$column adjusted with $25 \mathrm{mM}$ HEPES buffer, $\mathrm{pH}$ 7.5. Additionally, the flow-through of this column, containing the protein, was heated for $30 \mathrm{~min}$ at $75^{\circ} \mathrm{C}$ and centrifuged for $30 \mathrm{~min}$ at $8,000 \times g\left(4^{\circ} \mathrm{C}\right)$. The heat treatment was performed to precipitate non-heat-stable proteins because mRFP is extremely heat stable and heat treatment does not affect the fluorescence of the protein (Verkhusha et al. 2003). The supernatant was subsequently passed onto the NTA agarose column and washed with $100 \mathrm{ml}$ of $50 \mathrm{mM}$ phosphate

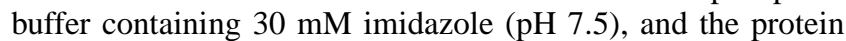
was eluted with $50 \mathrm{mM}$ phosphate buffer containing $300 \mathrm{mM}$ imidazole adjusted to $\mathrm{pH}$ 7.5. Finally, the protein was subjected onto a QAE agarose column, washed with buffer containing $100 \mathrm{mM} \mathrm{NaCl}$, and eluted with $200 \mathrm{mM} \mathrm{NaCl}$, and fractions were analyzed by sodium dodecyl sulfate polyacrylamide gel electrophoresis (SDS-PAGE).

\section{Purification of AVR3a ${ }^{22-59} \mathrm{mRFP}(\mathrm{His})_{6}$.}

The French press supernatant was adjusted to $\mathrm{pH} 5.4$ and passed through the QAE column. The flow-through of this column was applied to the $\mathrm{SO}_{3}{ }^{-}$column adjusted with $50 \mathrm{mM}$ sodium phosphate buffer $\mathrm{pH} 5.4$ and was washed with 5 volumes of the same buffer. From this column the protein was eluted with $200 \mathrm{mM}$ phosphate buffer adjusted to $\mathrm{pH}$ 7.5. The eluted fractions containing the mRFP construct were passed through the NTA agarose column. Subsequently, the column was washed with $100 \mathrm{ml} 50 \mathrm{mM}$ phosphate buffer containing 30 $\mathrm{mM}$ imidazole $(\mathrm{pH} 7.5)$ and the protein was eluted with 50 $\mathrm{mM}$ phosphate buffer containing $300 \mathrm{mM}$ imidazole adjusted to $\mathrm{pH} 7.5$ and fractions were analyzed by SDS-PAGE.

\section{Purification of (His) ${ }_{6} \mathbf{A v r 1 b}^{33-71}$ GFP.}

The French press supernatant passed through the $\mathrm{SO}_{3}{ }^{-}$column. Subsequently, the flow-through of this column was applied to the QAE column adjusted with $50 \mathrm{mM}$ sodium phosphate buffer, $\mathrm{pH} 7.5$, and was washed with five volumes of the same buffer. From this column, the protein was eluted with $50 \mathrm{mM}$ phosphate buffer containing $350 \mathrm{mM} \mathrm{NaCl}$ adjusted to $\mathrm{pH}$ 7.5. The eluted fractions containing the protein construct were passed through the NTA agarose column. Sub- sequently, the column was washed with $100 \mathrm{ml}$ of $50 \mathrm{mM}$ phosphate buffer containing $30 \mathrm{mM}$ imidazole $(\mathrm{pH} 7.5)$ and the protein was eluted with $50 \mathrm{mM}$ phosphate buffer containing $300 \mathrm{mM}$ imidazole adjusted to $\mathrm{pH} 7.5$, and fractions were analyzed by SDS-PAGE.

Generally, after purification, all fractions of pure protein were dialyzed twice for $3 \mathrm{~h}$ and once overnight against $50 \mathrm{mM}$ sodium phosphate buffer, $\mathrm{pH} 7.5$.

\section{Live cell imaging.}

RTG-2, Hek293, and A549 cells. Cell culture maintenance and procedure of confluent layer growth on cover slips have been described previously (van West et al. 2010; Wawra et al. 2012). HEK 293 and A549 cells were also handled according to this protocol, with the exception that Dulbecco's modified eagle medium (DMEM; Life Technologies Corp., Paisley, U.K.) medium was used and the cells were grown at $37^{\circ} \mathrm{C}$ in an atmosphere of $5 \% \mathrm{CO}_{2}$. The washed cover slips were transferred to optical petri dishes (diameter $3 \mathrm{~cm}$ ) and covered with the respective media containing $10 \%$ fetal calf serum (FCS) and the mRFP-tagged proteins at the indicated concentrations and temperatures. For the experiments performed at $\mathrm{pH} 5.8$, the respective medium containing FCS was adjusted. Before imaging, the cells were washed three times for $5 \mathrm{~min}$ in phosphate-buffered saline (PBS), two times for 5 min with PBS adjusted to $\mathrm{pH} 5.5$, two times for $5 \mathrm{~min}$ in PBS adjusted to $\mathrm{pH}$ 8.5, and, finally, two times for $1 \mathrm{~min}$ with L15 medium containing 10\% FCS (DMEM medium for HEK293 and A549 cells). Images were recorded using a Zeiss LSM510 confocal microscope equipped with a water-dipping lens. All images were obtained using the same microscope settings for all treatments. The microscope settings were optical slice $=2 \mu \mathrm{m}$; red channel, excitation $=543 \mathrm{~nm}$, detector gain $=750$, and filter setting = LP $560 \mathrm{~nm}$; and green channel, excitation $=488 \mathrm{~nm}$, detector gain $=750$, and filter setting $=$ BP 505-550

Onion cell translocation assay. Onion skin epidermal cells were washed three times for 5 min with $25 \mathrm{mM}$ sodium phosphate buffer, $\mathrm{pH} 7.5$, before applying the protein at the indicated concentration in $25 \mathrm{mM}$ sodium phosphate buffer containing 10\% BSA (to block unspecific protein binding sites). Incubations were carried out as indicated. After incubation, the epidermal skin was washed five times for $10 \mathrm{~min}$ with PBS and imaged on a Zeiss LSM 510 confocal microscope equipped with a water-dipping lens. Settings were optical slice $=2 \mu \mathrm{m}$; red channel, excitation $=543 \mathrm{~nm}$, detector gain $=750$, and filter setting = LP $560 \mathrm{~nm}$; and green channel, excitation = $488 \mathrm{~nm}$, detector gain $=750$, and filter setting = BP 505-550.

Soybean root uptake assay. The soybean root uptake assay was performed as described by Kale and associates (2010), with small alterations. In brief, $1.5-\mathrm{cm}$ root-tip pieces of 3day-old soybean seedlings grown in vermiculite at $28^{\circ} \mathrm{C}$ were incubated for 13 to $15 \mathrm{~h}$ in a $50 \mathrm{mM}$ phosphate buffer, $\mathrm{pH} 7$ or 5.8 , including the tested proteins, at a final concentration of 15 $\mu \mathrm{M}$. Additionally, the roots were washed for $3 \mathrm{~h}$ in $50 \mathrm{ml}$ of 50 $\mathrm{mM}$ phosphate buffer, $\mathrm{pH}$ 7. Confocal microscopy was performed as described by Djamei and associates (2011). To exclude the possibility of variety-specific behavior, we utilized soybean seed that were kindly provided by B. Tyler, Oregon State University, U.S.A.

Arabidopsis roots uptake assay. The Arabidopsis root uptake was essentially performed as the soybean root uptake assay. Arabidopsis seedlings ( 2 weeks old) were taken from $1 / 2$ Murashige Skoog cultures; washed in $50 \mathrm{mM}$ sodium phosphate buffer, $\mathrm{pH} 7.2$; and incubated with $3 \mu \mathrm{M}$ each protein construct for $1 \mathrm{~h}$ in $50 \mathrm{mM}$ sodium phosphate buffer, $\mathrm{pH} 7.2$, followed by washing with buffer (three times for $15 \mathrm{~min}$ each). Fluorescence signals were detected for AVR $3 \mathrm{a}^{22-59} \mathrm{mRFP}(\mathrm{His})_{6}$ 
and (His) ${ }_{6}$ Avr1 $1 b^{33-71}$ GFP using fluorescence microscopy (Eclipse 80i; Nikon, Duesseldorf, Germany) and an FITC filter for GFP fluorescence $\left(\lambda_{\mathrm{EX}} 465\right.$ to $495 \mathrm{~nm}, \lambda_{\mathrm{DM}} 505 \mathrm{~nm}, \lambda_{\mathrm{BA}}$ 515 to $555 \mathrm{~nm})$ or a tetramethyl rhodamine isothiocyanate filter for RFP fluorescence $\left(\lambda_{\mathrm{EX}} 540 / 20 \mathrm{~nm}, \lambda_{\mathrm{DM}} 565 \mathrm{~nm}, \lambda_{\mathrm{BA}}\right.$ $605 / 55 \mathrm{~nm})$.

Tobacco leaf infiltration. Leaves of 6-week-old Nicotiana tabacum plants were infiltrated with $20 \mu \mathrm{l}$ of a $15-\mu \mathrm{M}$ protein solution. Images were taken $1.5 \mathrm{~h}$ after infiltration using confocal laser scanning microscopy (TCS SP2; Leica, Wetzlar, Germany). The fluorescence was excited with an argon/krypton laser for GFP ( $\lambda_{\mathrm{EX}} 488 \mathrm{~nm}$ and $\lambda_{\mathrm{em}} 500$ to $\left.540 \mathrm{~nm}\right)$ and with a helium/neon laser for RFP ( $\lambda_{\mathrm{EX}} 543 \mathrm{~nm}$ and $\lambda_{\text {em }} 560$ to $615 \mathrm{~nm})$

\section{ACKNOWLEDGMENTS}

Our work is supported by the Biotechnology and Biological Sciences Research Council and 5) Natural Environment Research Council (S. Wawra and P. van West), the University of Aberdeen and The Royal Society (P. van West), the collaborative research Center SFB593 and the LOEWE program of the State of Hesse (A. Djamei and R. Kahmann), and the Deutsche Forschungsgemeinschaft (German Research Foundation grant NU 70/9-1 project 14061014) (I. Albert and T. Nürnberger).

\section{LITERATURE CITED}

Baxter. L., Tripathy. S., Ishaque. N., Boot. N., Cabral, A., Kemen, E., Thines, M., Ah-Fong, A., Anderson, R., Badejoko, W., Bittner-Eddy, P., Boore, J. L., Chibucos, M. C., Coates, M., Dehal, P., Delehaunty, K., Dong, S., Downton, P., Dumas, B., Fabro, G., Fronick, C., Fuerstenberg, S. I., Fulton, L., Gaulin, E., Govers, F., Hughes, L., Humphray, S., Jiang, R. H. Y., Judelson, H., Kamoun, S., Kyung, K., Meijer, H., Minx, P., Morris, P., Nelson, J., Phuntumart, V., Qutob, D., Rehmany, A., RougonCardoso, A., Ryden, P., Torto-Alalibo, T., Studholme, D., Wang, Y., Win, J., Wood, J., Clifton, S. W., Rogers, J., Van den Ackerveken, G., Jones, J. D. G., McDowell, J. M., Beynon, J., and Tyler, B. M. 2010. Signatures of adaptation to obligate biotrophy in the Hyaloperonospora arabidopsidis genome. Science 330:1549-1551.

Bernoux, M., Ellis, J. G., and Dodds, P. N. 2011. New insights in plant immunity signaling activation. Curr. Opin. Plant Biol. 14:512-518.

Birch, P. R., Armstrong, M., Bos, J., Boevink, P., Gilroy, E. M., Taylor, R. M., Wawra, S., Pritchard, L., Conti, L., Ewan, R., Whisson, S. C., van West, P., Sadanandom, A., and Kamoun, S. 2009. Towards understanding the virulence functions of RXLR effectors of the oomycete plant pathogen Phytophthora infestans. J. Exp. Bot. 60:1133-1140.

Bos J. I., Kanneganti, T. D., Young, C., Cakir, C., Huitema, E., Win, J., Armstrong, M. R., Birch, P. R., and Kamoun, S. 2006. The C-terminal half of Phytophthora infestans RXLR effector AVR3a is sufficient to trigger R3a-mediated hypersensitivity and suppress INF1-induced cell death in Nicotiana benthamiana. Plant J. 48:165-176.

Bos, J. I., Armstrong, M. R., Gilroy, E. M., Boevink, P. C., Hein, I., Taylor, R. M., Zhendong, T., Engelhardt, S., Vetukuri, R. R., Harrower, B., Dixelius, C., Bryan, G., Sadanandom, A., Whisson, S. C., Kamoun, S., and Birch, P. R. 2010. Phytophthora infestans effector AVR3a is essential for virulence and manipulates plant immunity by stabilizing host E3 ligase CMPG1. Proc. Natl. Acad. Sci. U.S.A. 107:9909-9914.

Boutemy, L. S., King, S. R., Win, J., Hughes, R. K., Clarke, T. A., Blumenschein, T. M., Kamoun, S., and Banfield, M. J. 2011. Structures of Phytophthora RXLR effector proteins: A conserved but adaptable fold underpins functional diversity. J. Biol. Chem. 286:3583435842 .

Bozkurt, T. O., Schornack, S., Banfield, M. J., and Kamoun, S. 2012. Oomycetes, effectors, and all that jazz. Curr. Opin. Plant Biol. 15:483492.

Djamei, A., Schipper, K., Rabe, F., Ghosh, A., Vincon, V., Kahnt, J., Osorio, S., Tohge, T., Fernie, A. R., Feussner, I., Feussner, K., Meinicke, P., Stierhof, Y. D., Schwarz, H., Macek, B., Mann, M., and Kahmann, R. 2011. Metabolic priming by a secreted fungal effector. Nature 478:395398.

Dou, D., Kale, S. D., Wang, X., Chen, Y., Wang, Q., Jiang, R. H., Arredondo, F. D., Anderson, R. G., Thakur, P. B., McDowell, J. M., Wang, Y., Tyler, B. M. 2008a. Conserved C-terminal motifs required for avirulence and suppression of cell death by Phytophthora sojae effector Avr1b. Plant Cell 20:1118-1133.

Dou, D., Kale, S. D., Wang, X., Jiang, R. H., Bruce, N. A., Arredondo, F.
D., Zhang, X., and Tyler, B. M. 2008b. RXLR-mediated entry of Phytophthora sojae effector Avrlb into soybean cells does not require pathogen-encoded machinery. Plant Cell 20:1930-1947.

Ellis, J. G., and Dodds, P. N. 2011. Showdown at the RXLR motif: Serious differences of opinion in how effector proteins from filamentous eukaryotic pathogens enter plant cells. Proc. Natl. Acad. Sci. U.S.A. 108:14381-14382.

Grouffaud, S., van West, P., Avrova, A. O., Birch, P. R., and Whisson, S. C. 2008. Plasmodium falciparum and Hyaloperonospora parasitica effector translocation motifs are functional in Phytophthora infestans. Microbiology 154:3743-3751.

Haas, B. J., Kamoun, S., Zody, M. C., Jiang, R. H., Handsaker, R. E., Cano, L. M., Grabherr, M., Kodira, C. D., Raffaele, S., Torto-Alalibo, T., Bozkurt, T. O., Ah-Fong, A. M., Alvarado, L., Anderson, V. L., Armstrong, M. R., Avrova, A., Baxter, L., Beynon, J., Boevink, P. C., Bollmann, S. R., Bos, J. I., Bulone, V., Cai, G., Cakir, C., Carrington, J. C., Chawner, M., Conti, L., Costanzo, S., Ewan, R., Fahlgren, N., Fischbach, M. A., Fugelstad, J., Gilroy, E. M., Gnerre, S., Green, P. J., Grenville-Briggs, L. J., Griffith, J., Grunwald, N. J., Horn, K., Horner, N. R., Hu, C. H., Huitema, E., Jeong, D. H., Jones, A. M., Jones, J. D., Jones, R. W., Karlsson, E. K., Kunjeti, S. G., Lamour, K., Liu, Z., Ma, L., Maclean, D., Chibucos, M. C., McDonald, H., McWalters, J., Meijer, H. J., Morgan, W., Morris, P. F., Munro, C. A., O’Neill, K., OspinaGiraldo, M., Pinzon, A., Pritchard, L., Ramsahoye, B., Ren, Q., Restrepo, S., Roy, S., Sadanandom, A., Savidor, A., Schornack, S., Schwartz, D. C., Schumann, U. D., Schwessinger, B., Seyer, L., Sharpe, T., Silvar, C., Song, J., Studholme, D. J., Sykes, S., Thines, M., van de Vondervoort, P. J., Phuntumart, V., Wawra, S., Weide, R., Win, J., Young, C., Zhou, S., Fry, W., Meyers, B. C., van West, P., Ristaino, J., Govers, F., Birch, P. R., Whisson, S. C., Judelson, H. S., and Nusbaum, C.. 2009. Genome sequence and analysis of the Irish potato famine pathogen Phytophthora infestans. Nature 461:393-398.

He, S. Y., Nomura, K., and Whittam, T. S. 2004. Type III protein secretion mechanism in mammalian and plant pathogens. Biochim. Biophys. Acta 1694:181-206.

Heim, R., Prasher, D. C., and Tsien, R. Y. 1994. Wavelength mutations and posttranslational autoxidation of green fluorescent protein. Proc. Natl. Acad. Sci. U.S.A. 91:12501-12504.

Hiller, G., and Weber, K. 1978. Radioimmunoassay for tubulin: A quantitative comparison of the tubulin content of different established tissue culture cells and tissues. Cell 14:795-804.

Kale, S. D., and Tyler, B. M. 2011. Entry of oomycete and fungal effectors into plant and animal host cells. Cell. Microbiol. 13:1839-1848.

Kale, S. D., Gu, B., Capelluto, D. G., Dou, D., Feldman, E., Rumore, A., Arredondo, F. D., Hanlon, R., Fudal, I., Rouxel, T., Lawrence, C. B., Shan, W., and Tyler, B. M. 2010. External lipid PI3P mediates entry of eukaryotic pathogen effectors into plant and animal host cells. Cell 142:284-295.

Kerrigan, A. M., and Brown, G. D. 2009. C-type lectins and phagocytosis. Immunobiology 214:562-575.

Liu, S.-L., Zhang, Z.-L., Sun, E.-Z., Peng, J., Xie, M., Tian, Z.-Q., Lin, Y., and Pang, D.-W. 2011. Visualizing the endocytic and exocytic processes of wheat germ agglutinin by quantum dot-based single-particle tracking. Biomaterials 32:7616-7624.

Malmstrom, J., Beck, M., Schmidt, A., Lange, V., Deutsch, E. W., and Aebersold, R. 2009. Proteome-wide cellular protein concentrations of the human pathogen Leptospira interrogans. Nature 460:762-765.

Mattoo, S., Lee, Y. M., and Dixon, J. E. 2007. Interactions of bacterial effector proteins with host proteins. Curr. Opin. Immunol. 19:392401.

Paungfoo-Lonhienne, C., Lonhienne, T. G., Rentsch, D., Robinson, N., Christie, M., Webb, R. I., Gamage, H. K., Carroll, B. J., Schenk, P. M., and Schmidt, S. 2008. Plants can use protein as a nitrogen source without assistance from other organisms. Proc. Natl. Acad. Sci. U.S.A. 105:4524-4529.

Plett, J. M., Kemppainen, M., Kale, S. D., Kohler, A., Legue, V., Brun, A., Tyler, B. M., Pardo, A. G., and Martin, F. 2011. A secreted effector protein of Laccaria bicolor is required for symbiosis development. Curr. Biol. 21:1197-1203.

Ravensdale, M., Nemri, A., Thrall, P. H., Ellis, J. G., and Dodds, P. N. 2011. Co-evolutionary interactions between host resistance and pathogen effector genes in flax rust disease. Mol. Plant Pathol. 12:93-102.

Rehmany, A. P., Gordon, A., Rose, L. E., Allen, R. L., Armstrong, M. R. Whisson, S. C., Kamoun, S., Tyler, B. M., Birch, P. R., and Beynon, J. L. 2005. Differential recognition of highly divergent downy mildew avirulence gene alleles by RPP1 resistance genes from two Arabidopsis lines. Plant Cell 17:1839-1850.

Reid, B. G., and Flynn, G. C. 1997. Chromophore formation in green fluorescent protein. Biochemistry 36:6786-6791.

Sharon, N. 1984. Carbohydrates as recognition determinants in phagocyto- 
sis and in lectin-mediated killing of target cells. Biol. Cell 51:239-245.

Stergiopoulos, I., and de Wit, P. J. 2009. Fungal effector proteins. Annu. Rev. Phytopathol. 47:233-263.

van West, P., de Bruijn, I., Minor, K. L., Phillips, A. J., Robertson, E. J., Wawra, S., Bain, J., Anderson, V. L., and Secombes, C. J. 2010. The putative RxLR effector protein SpHtp1 from the fish pathogenic oomycete Saprolegnia parasitica is translocated into fish cells. FEMS Microbiol. Lett. 310:127-137.

Verkhusha, V. V., Kuznetsova, I. M., Stepanenko, O. V., Zaraisky, A. G., Shavlovsky, M. M., Turoverov, K. K., and Uversky, V. N. 2003. High stability of Discosoma DsRed as compared to Aequorea EGFP. Biochemistry 42:7879-7884.

Wawra, S., Bain, J., Durward, E., de Bruijn, I., Minor, K. L., Matena, A., Löbach, L., Whisson, S. C., Bayer, P., Porter, A. J., Birch, P. R. J.,
Secombes, C. J., and van West, P. 2012. Host-targeting protein 1 (SpHtp1) from the oomycete Saprolegnia parasitica translocates specifically into fish cells in a tyrosine-O-sulphate-dependent manner. Proc. Natl. Acad. Sci. U.S.A. 109:2096-2101.

Whisson, S. C., Boevink, P. C., Moleleki, L., Avrova, A. O., Morales, J. G., Gilroy, E. M., Armstrong, M. R., Grouffaud, S., van West, P. Chapman, S., Hein, I., Toth, I. K., Pritchard, L., and Birch, P. R. 2007. A translocation signal for delivery of oomycete effector proteins into host plant cells. Nature 450:115-118.

Yaeno, T., Li, H., Chaparro-Garcia, A., Schornack, S., Koshiba, S., Watanabe, S., Kigawa, T., Kamoun, S., and Shirasu, K. 2011. Phosphatidylinositol monophosphate-binding interface in the oomycete RXLR effector AVR3a is required for its stability in host cells to modulate plant immunity. Proc. Natl. Acad. Sci. U.S.A. 108:14682-14687. 